\title{
Defined and Semi-defined Media for the Growth of Amoebae of Physarum polycephalum
}

\author{
By CLARE H. R. MCCULLOUGH AND JENNIFER DEE \\ Department of Genetics, The University, Leicester LEI $7 R H$
}

(Received 26 November 1975; revised Io January 1976)

SUMMARY

\begin{abstract}
Amoebae of the true slime mould Physarum polycephalum were cultured in two fully-defined liquid media containing amino acids, glucose, three vitamins and a buffered salts solution. Absolute requirements were demonstrated for methionine, haematin, thiamine and biotin, all of which were known to be specific requirements of the plasmodial stage. Methods are described for large-scale culture in three semi-defined media.
\end{abstract}

\section{INTRODUCTION}

The true slime mould Physarum polycephalum is useful for studying many biological processes, including the mitotic cycle, DNA synthesis, protoplasmic streaming and cell differentiation (reviewed by Hüttermann, 1973; Dee, 1975). However, although the multinucleate plasmodial stage can be cultured on rich synthetic and defined media (Daniel \& Baldwin, 1964), and has been the subject of many biochemical studies, very little work has been reported on the nutrition or biochemistry of the other vegetative stage in the life-cycle, the uninucleate amoeba. For genetic work, in which the culture of amoebae is essential, a lawn of living or formalin-killed Escherichia coli on agar has generally been used as the culture medium.

Goodman (1972) reported the first soluble liquid medium for $P$. polycephalum amoebae; however, this had disadvantages for large-scale cultures since some constituents were expensive and could not be autoclaved. It was also unsuitable for some experiments because it contained a large quantity of protein [3\% (w/v) bovine serum albumin]. One aim of the present work was to develop methods for culturing amoebae in autoclavable synthetic media in sufficient quantities for comparative biochemical studies of amoebae and plasmodia. Henney, Asgari \& Henney (1974) reported growth of $P$. flavicomum amoebae in two partially-defined media which were originally devised for $P$. flavicomum plasmodia (Henney \& Henney, 1968). These two media have been used as a basis for investigating the specific requirements of $P$. polycephalum amoebae.

A second aim of our work was to find a fully-defined medium for $P$. polycephalum amoebae so that auxotrophic mutants could be isolated and genetically analysed using amoebae. Mutant isolation and analysis are possible in plasmodia, but are laborious (Cooke \& Dee, 1975). A chemically defined medium would also allow the study of aspects of amoebal metabolism, such as the uptake of single amino acids.

\section{METHODS}

Amoebal strains. RSD4 is a heterothallic clone, mating-type I $\left(m t_{1}\right)$ (Haugli, 197I), originally described by Dr F. B. Haugli, University of Tromsø, Norway, and obtained from him. The same strain was cultured in axenic medium by Goodman (1972). CLd is a strain 
of the Colonia isolate, which forms plasmodia in amoebal clones under appropriate conditions; it carries allele $m t_{\mathrm{h}}$ at the mating-type locus (Cooke \& Dee, 1974). APTI is a mutant clone isolated after mutagenesis of $m t_{\mathrm{h}}$ amoebae. It fails to form plasmodia in

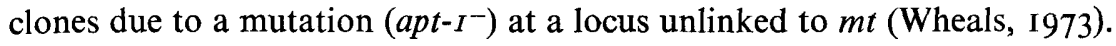

Culture vessels. For nutritional tests, cultures $(\mathrm{I} \cdot 0$ to $\mathrm{I} \cdot 5 \mathrm{ml})$ were set up in $100 \times 16 \mathrm{~mm}$ plastic tubes (supplied sterile with caps by Sterilin, Teddington, Middlesex), and incubated horizontally in stationary racks. Larger cultures were grown in $140 \mathrm{ml}$ medical flats (5 to IO $\mathrm{ml}$ cultures) incubated horizontally, or in conical flasks (25 to $500 \mathrm{ml}$ cultures) on a rotary shaker. Flask capacities were approximately $5 \times$ culture volume. All cultures were incubated at $25^{\circ} \mathrm{C}$ in the dark.

Inoculation, subculturing and sampling. Amoebal strains to be grown axenically were freed from live $E$. coli by allowing them to migrate along a streak of formalin-killed $E$. coli (Haugli, 197I) on liver infusion agar (Oxoid liver infusion powder, I $\mathrm{g} \mathrm{l}^{-1}$; agar $20 \mathrm{~g}^{-1}$ ). After two migrations, the amoebae were plated out on a lawn of formalin-killed $E$. coli in order to increase their number, and were then washed off the plates with axenic medium $\left(2 \mathrm{ml} /\right.$ plate) to give a density of approximately $10^{6} \mathrm{cells} / \mathrm{ml}$ in the axenic cultures. In newlyestablished cultures and in subcultures it was necessary to use a large inoculum; if initial cell numbers were less than $5 \times 10^{5}$ cells $/ \mathrm{ml}$, no growth was obtained.

For growth estimations, the culture was thoroughly mixed and a small sample transferred with a Pasteur pipette to two chambers on a haemocytometer slide. Duplicate counts were made on each sample.

Subcultures were made, after counting, by transferring an appropriate volume of the culture to fresh medium to give a cell density of approximately $10^{6} \mathrm{cells} / \mathrm{ml}$ in the new culture. It was not practicable to free the amoebae of old medium by centrifuging and washing before subculturing because the cells grew poorly after such treatment.

Media. The compositions of the defined and semi-defined media used are given in Table I. Sterilization of all components was achieved by autoclaving ( $15 \mathrm{~min}$ at $\mathrm{I} 2 \mathrm{I}{ }^{\circ} \mathrm{C}$ ), except for bovine serum albumin (BSA) which was filter-sterilized through a Sartorius membrane filter (pore size $0.45 \mu \mathrm{m}$ ), and beef embryo extract (EE) which was reconstituted in sterile water.

Chemicals. Glass single-distilled water was used throughout. Inorganic chemicals were analytical grade. Other media constituents were: beef embryo extract (Grand Island Biological Co.; supplied by Tissue Culture Services, Slough SLI 6BY); bovine serum albumin, Cohn fraction V (Sigma); Bacto yeast extract (Difco); thiamine- $\mathrm{HCl}$, biotin and amino acids (Sigma); haematin (Koch-Light). Several forms of casein hydrolysate were used with equal success: pancreatic digest of casein, N-Z Case (Sheffield Chemical; supplied by KW-Revai Chemicals, London, WCIV 6EF); Bacto-Casitone (Difco); enzymic casein hydrolysate from milk (Sigma).

\section{RESULTS}

\section{Morphology of amoebae in liquid media}

Physarum polycephalum amoebae can exist in three different forms, depending on the conditions. When grown on a lawn of E. coli, they have typical amoeboid morphology, with pseudopodia and contractile vacuoles. When the food supply is exhausted, they form rounded cysts which remain viable for many months. Amoebae placed in water without nutrients develop flagella and swim actively.

In the liquid media described in this paper, the majority of cells seen during sampling 


\section{Table I. Composition of semi-defined and defined media for Physarum polycephalum myxamoebae}

Quantities given are for $100 \mathrm{ml}$ of medium. The final $\mathrm{pH}$ of all media was 4:7: SD and BTC needed little adjustment; ADM-I 3 was adjusted to the correct $\mathrm{pH}$ with $\mathrm{KOH}$ before autoclaving. For modified Goodman medium, the basal salts solution with trace elements solution and glucose was made up to $68 \mathrm{ml}$, the $\mathrm{pH}$ was adjusted and the mixture autoclaved before adding $3 \mathrm{I} \cdot 5 \mathrm{ml}$ sterile $10 \%(\mathrm{w} / \mathrm{v})$ BSA stock solution and $\mathrm{I} \cdot 25 \mathrm{ml}$ reconstituted embryo extract.

\begin{tabular}{|c|c|c|c|c|c|c|c|}
\hline Medium & $\begin{array}{l}\text { Nitrogenous compon } \\
\text { (mg) }\end{array}$ & & $\begin{array}{c}\text { Vitamin-yie } \\
\text { compone } \\
(\mu \mathrm{g})\end{array}$ & lding & $\begin{array}{l}\text { Glucose } \\
(\mathrm{g})\end{array}$ & $\begin{array}{l}\text { Basal } \\
\text { salts } \\
\text { solution } \dagger \\
(\mathrm{ml})\end{array}$ & $\begin{array}{l}\text { Trace } \\
\text { element } \\
\text { solution } \\
\text { (ml) }\end{array}$ \\
\hline $\begin{array}{l}\text { Modified } \\
\text { Goodman§ }\end{array}$ & Bovine serum albumin & 3150 & Embryo extract & $\sim 3 \times 10^{4}$ & 0.2 & 10 & 0.01 \\
\hline $\mathrm{SD} \|$ & Casein hydrolysate & 500 & $\begin{array}{l}\text { Yeast extract } \\
\text { Haematin }\end{array}$ & $\begin{array}{r}0.5 \times 10^{6} \\
500\end{array}$ & 0.5 & IO & 0.01 \\
\hline BTC $\|$ & Casein hydrolysate & 500 & $\begin{array}{l}\text { Biotin } \\
\text { Thiamine } \\
\text { Haematin }\end{array}$ & $\begin{array}{r}10 \\
20 \\
500\end{array}$ & 0.5 & 10 & 0.01 \\
\hline ADM-I 3 & $\begin{array}{l}\text { L-Alanine } \\
\text { L-Arginine- } \mathrm{HCl} \\
\text { L-Cysteine } \\
\text { Glycine } \\
\text { L-Histidine-HCl } \\
\text { L-Isoleucine } \\
\text { L-Leucine } \\
\text { L-Lysine } \\
\text { L-Methionine } \\
\text { L-Phenylalanine } \\
\text { L-Serine } \\
\text { L-Threonine } \\
\text { L-Valine }\end{array}$ & $\begin{array}{l}2 \cdot 73 \\
2 \cdot 04 \\
1 \cdot 30 \\
1 \cdot 53 \\
0.91 \\
0.59 \\
3.54 \\
2 \cdot 13 \\
0.43 \\
0.73 \\
0.79 \\
0.63 \\
0.76\end{array}$ & $\begin{array}{l}\text { Biotin } \\
\text { Thiamine } \\
\text { Haematin }\end{array}$ & $\begin{array}{r}10 \\
20 \\
500\end{array}$ & 0.5 & IO & 0.01 \\
\hline ADM-1 2 & As ADM-13, but lackin & g L L-pl & nylalanine & & & & \\
\hline ADM-5 & $\begin{array}{l}\text { L-Alanine } \\
\text { L-Arginine-HCl } \\
\text { Glycine } \\
\text { L-Leucine } \\
\text { L-Methionine }\end{array}$ & $\begin{array}{l}2 \cdot 73 \\
2 \cdot 04 \\
I \cdot 53 \\
3 \cdot 54 \\
0.43\end{array}$ & $\begin{array}{l}\text { Biotin } \\
\text { Thiamine } \\
\text { Haematin }\end{array}$ & $\begin{array}{r}10 \\
20 \\
500\end{array}$ & 0.5 & 10 & 0.01 \\
\hline
\end{tabular}

\footnotetext{
ADM-4 As ADM-5, but lacking L-leucine
}

* Haematin was made up separately: $0.05 \mathrm{~g}$ was added to $\mathrm{I} 00 \mathrm{ml}$ of $\mathrm{I} \%(\mathrm{w} / \mathrm{v}) \mathrm{NaOH}$, autoclaved and I $\mathrm{ml}$ was added per $100 \mathrm{ml}$ sterile medium.

$\dagger$ Basal salts solution ( $\mathrm{pH}_{4}{ }^{\circ}$ ) (Henney \& Henney, 1968). To about $700 \mathrm{ml}$ glass-distilled water (final volume $1000 \mathrm{ml}$ ) was added successively, with stirring, (g): citric acid, $29 \cdot 78 ; \mathrm{K}_{2} \mathrm{HPO}_{4}, 33 \cdot 10 ; \mathrm{NaCl}, 2 \cdot 50$; $\mathrm{MgSO}_{4} \cdot 7 \mathrm{H}_{2} \mathrm{O}, \mathrm{I} \cdot 00 ; \mathrm{CaCl}_{2} \cdot 2 \mathrm{H}_{2} \mathrm{O}, 0.50$.

$\ddagger$ Trace elements solution (Henney \& Henney, 1968). The following compounds were dissolved successively in $95 \mathrm{ml}$ glass-distilled water, with stirring, (g): citric acid, $5.00 ; \mathrm{ZnSO}_{4} \cdot 7 \mathrm{H}_{2} \mathrm{O}, 5 \cdot 00 ; \mathrm{Fe}\left(\mathrm{NH}_{4}\right)_{2}\left(\mathrm{SO}_{4}\right)_{2}$. $6 \mathrm{H}_{2} \mathrm{O}, \mathrm{I} \cdot 00 ; \mathrm{CuSO}_{4} \cdot 5 \mathrm{H}_{2} \mathrm{O}, 0.25 ; \mathrm{MnSO}_{4} . \mathrm{H}_{2} \mathrm{O}, 0.05 ; \mathrm{H}_{3} \mathrm{BO}_{3}$ anhydrous, $0.05 ; \mathrm{Na}_{2} \mathrm{MoO}_{4} .2 \mathrm{H}_{2} \mathrm{O}, 0.05 ;$ $\mathrm{CoCl}_{2} \cdot 6 \mathrm{H}_{2} \mathrm{O}$, 0.05.

$\S$ Goodman ( I 972).

II Henney et al. (1974).

were amoeboid, and cysts were formed in cultures reaching a growth plateau. Flagellated cells were seen occasionally, but amounted to less than $0.1 \%$ of the total.

\section{Semi-defined media}

Cultures of RSD4 amoebae were grown initially in the medium described by Goodman (1972). Numerous modifications to this medium (Table I), including the omission of 


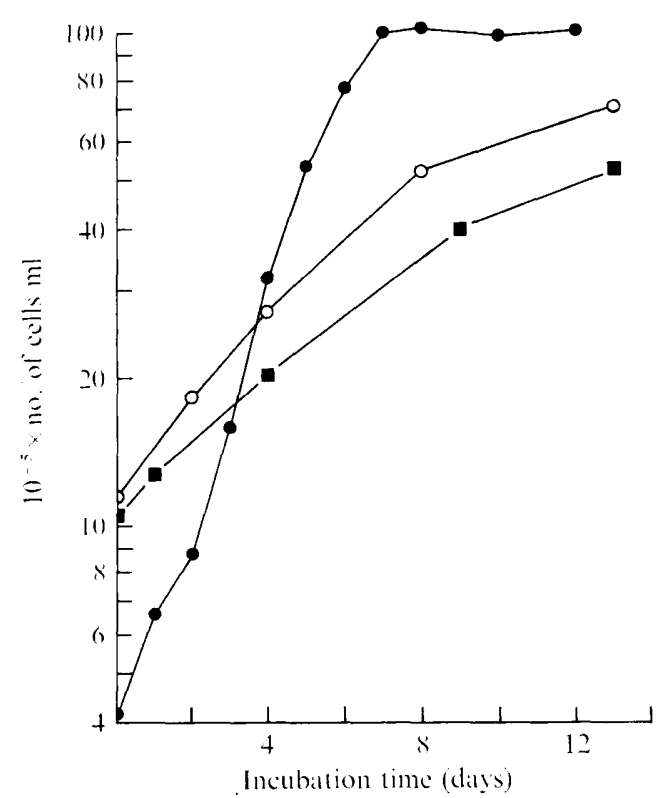

Fig. I

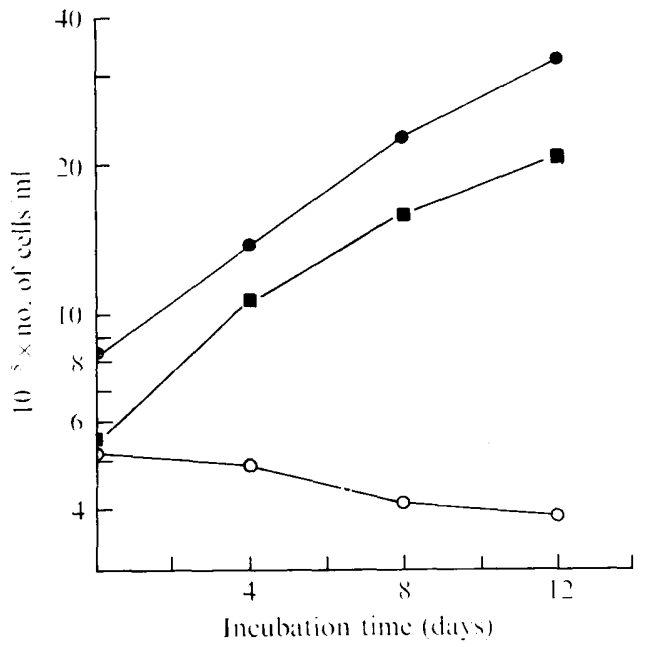

Fig. 2

Fig. I. Growth of RSD4 amoebae in three semi-defined media: $\bullet$, modified Goodman; $\bigcirc$, SD; $\square$, BTC.

Fig. 2. Test for biotin requirement of RSD4 amoebae using avidin in ADM-I 3 medium. Cells were transferred to the media containing avidin from ADM-I 3 lacking biotin. 9 , Growth in ADM-I3; $O$, growth in ADM-13 lacking biotin containing avidin $\left(0.05\right.$ units $\left.\mathrm{ml}^{-1}\right)$; $\mathbf{\square}$, growth in ADM-13 containing avidin $\left(0.05\right.$ units $\left.\mathrm{ml}^{-1}\right)$ and excess biotin $\left(0.4 \mu \mathrm{g} \mathrm{ml}^{-1}\right)$.

peptone, liver infusion and chick embryo extract, the substitution of citrate-phosphate for phosphate buffer, the inclusion of a wider range of salts, and alteration of the $\mathrm{pH}$ from $6 \cdot 3$ to 4.7 , resulted in an improved growth rate and yield (Fig. I). Despite many attempts, we failed to replace BSA and beef embryo extract in the medium.

Henney et al. (1974) reported growth of $P$. flavicomum amoebae in two partially-defined media, and so RSD4 amoebae were inoculated into both these media. They were identical in composition except that one (SD) contained yeast extract, and the other (BTC), biotin and thiamine (Table I). After a period of several weeks during which growth was extremely slow, good growth rates and yields were obtained in both media (Fig. I) and these have been maintained through many subcultures. Doubling times were 2 days in SD and 3 to 4 days in BTC. Stock cultures of amoebal strains CLd and APTI are also maintained currently in both media.

\section{Fully-defined media}

Cultures of RSD4 growing in BTC medium were used to provide inocula for tests of fullydefined media. The defined medium, AV-40, developed for $\boldsymbol{P}$. polycephalum plasmodia (Daniel et al., 1963) had already been tested for amoebal culture without success (Goodman, I972). We found that a slightly modified form of AV-40, lacking phenylalanine and tryptophan, supported some growth of RSD4 amoebae, but this ceased in the fourth subculture.

$A D M$-I 2 and $A D M$ - I3. The $\mathrm{I} 2$ amino acids used in our modified AV-40 medium were combined with the glucose, basal salts, vitamins and trace-elements used in BTC medium. 
This new medium (ADM-I2) supported growth of RSD4 amoebae through numerous subcultures over a period of seven months. The minimum doubling time observed was $4 \frac{1}{2}$ days. The addition of phenylalanine resulted in slightly improved growth and it is now routinely included in the medium, renamed ADM-I3 (Table I). ADM-I3 medium, lacking glucose, failed to support growth of RSD4 amoebae.

$A D M-4$ and $A D M-5$. In an attempt to simplify the composition of the defined medium, seven amino acids were omitted from ADM-I3, leaving alanine, arginine, glycine and methionine, the four present in the minimal medium OV-40 developed for $P$. polycephalum plasmodia (Daniel et al., I963). This simplified medium (ADM-4) supported growth of RSD4 amoebae through three subcultures. In the fourth subculture growth ceased although the cells appeared healthy and were used to inoculate further test media. Increasing the concentrations of alanine, arginine and glycine in ADM-4 to give a total amino-acid content equivalent to ADM-I 3 did not improve growth.

The seven amino acids omitted from ADM-4 were then re-introduced in pairs and the media were inoculated with RSD4 amoebae from the fourth subculture in ADM-4. Growth in the medium containing leucine and serine was markedly better than in the other media. Leucine and serine were therefore added singly to ADM-4 and the media inoculated as before with RSD4 amoebae from ADM-4. No growth occurred in the control or in the medium containing serine but the medium containing leucine supported growth for two weeks. Growth in this medium (ADM-5) has now continued through four subcultures.

\section{Demonstration of requirements}

Methionine. Methionine is the only essential amino acid for P. polycephalum plasmodia (Daniel et al., 1963). Cultures of RSD4 amoebae were inoculated in ADM-I2 lacking methionine. In the fourth subculture growth ceased, indicating that methionine is also an absolute requirement of amoebae.

Vitamins. Since RSD4 amoebae grew through many subcultures in BTC and ADM-I2, in which the only vitamins were biotin, thiamine and haematin, it was concluded that the amoebae, like the plasmodia (Daniel et al., 1963) required no other vitamins.

Requirement for thiamine and haematin had previously been indicated by experiments in which amoebae were fed on $E$. coli pre-treated with hot trichloroacetic acid and washed free of acid-soluble materials. The treated bacteria alone failed to support growth of amoebae but growth was restored when thiamine and haematin were added (C. E. Holt, L. Davidow \& J. Dee, unpublished results).

Haematin requirement was demonstrated by inoculating RSD4 amoebae into SD medium and SD medium lacking haematin; growth ceased in the second subculture in the absence of haematin.

Thiamine requirement could not be demonstrated clearly until a defined medium was developed. Amoebae of strain RSD4 grew through seven subcultures in BTC medium lacking thiamine although yields were lower than in controls. When amoebae from the seventh subculture without thiamine were transferred to ADM-I 3 medium lacking thiamine, growth ceased immediately. It was concluded that the casein hydrolysate in BTC medium contained sufficient thiamine to support some growth.

Biotin dependence of RSD4 amoebae could not at first be demonstrated in either BTC medium or ADM-13. The cells grew at the same rate as in controls through six subcultures in BTC medium with no added biotin, and through a further two subcultures in ADM-I 3 lacking biotin. The cells were then transferred to ADM-I3, without added biotin, containing 
Table 2. The effect of ferrous ion concentration on the growth of RSD4 amoebae in $S D$ medium

In each subculture, RSD4 amoebae were grown for 7 days in $\mathrm{SD}$ medium containing $\mathrm{FeCl}_{2} \cdot 4 \mathrm{H}_{2} \mathrm{O}$ at concentrations of $6.0 \times 10^{-8} \mathrm{M}\left(\mathrm{SD}\right.$ control) or $2.5 \times 10^{-4} \mathrm{M}\left(\mathrm{high}^{\mathrm{Fe}} \mathrm{Fe}^{2+}\right.$ ).

\begin{tabular}{|c|c|c|c|c|}
\hline Subculture & Medium & $\begin{array}{c}\mathrm{IO}^{-6} \times \text { Initial } \\
\text { cell no. } \\
(\text { cells } / \mathrm{ml})\end{array}$ & $\begin{array}{c}\mathrm{IO}^{-6} \times \text { Final } \\
\text { cell no. } \\
(\text { cells } / \mathrm{ml})\end{array}$ & $\begin{array}{c}\text { No. of } \\
\text { doublings }\end{array}$ \\
\hline Ist & $\begin{array}{l}\text { SD control } \\
\text { high } \mathrm{Fe}^{2+}\end{array}$ & $\begin{array}{l}3 \cdot 6 \\
4 \cdot 1\end{array}$ & $\begin{array}{r}10 \cdot 0 \\
9 \cdot I\end{array}$ & $\begin{array}{l}I \cdot 4 \\
I \cdot I\end{array}$ \\
\hline 2nd & $\begin{array}{l}\text { SD control } \\
\text { high } \mathrm{Fe}^{2+}\end{array}$ & $\begin{array}{l}I \cdot 4 \\
\mathrm{I} \cdot 6\end{array}$ & $\begin{array}{l}9 \cdot 0 \\
7 \cdot 6\end{array}$ & $\begin{array}{l}2 \cdot 6 \\
2 \cdot 2\end{array}$ \\
\hline 3 rd & $\begin{array}{l}\text { SD control } \\
\text { high } \mathrm{Fe}^{2+}\end{array}$ & $\begin{array}{l}1.4 \\
1.5\end{array}$ & $\begin{array}{r}11 \cdot 0 \\
6 \cdot 9\end{array}$ & $\begin{array}{l}3 \cdot 0 \\
2 \cdot I\end{array}$ \\
\hline
\end{tabular}

Table 3. The effect of $p H$ on growth of RSD4 amoebae in SD medium

RSD4 amoebae were grown in SD medium for 7 days at various $\mathrm{pH}$ values. The results shown are from two separate experiments: the first over the range $\mathrm{pH}_{3.5}$ to $5^{\circ} 0$, the second $\mathrm{pH} 4.5$ to 6.5 .

\begin{tabular}{|c|c|c|c|c|c|}
\hline \multicolumn{2}{|c|}{ Initial $\mathrm{pH}$} & \multirow{2}{*}{$\begin{array}{c}10^{-6} \times \text { Initial } \\
\text { cell no. } \\
(\text { cells } / \mathrm{ml})\end{array}$} & \multirow{2}{*}{$\begin{array}{c}\mathrm{IO}^{-6} \times \text { Final } \\
\text { cell no. } \\
(\text { cells } / \mathrm{ml})\end{array}$} & \multirow{2}{*}{$\begin{array}{c}\text { No. of } \\
\text { doublings }\end{array}$} & \multirow[b]{2}{*}{ Final $\mathrm{pH}$} \\
\hline Expt I & Expt 2 & & & & \\
\hline $3 \cdot 5$ & & $2 \cdot I$ & $I \cdot 6$ & - & $3 \cdot 7$ \\
\hline $4 \cdot 0$ & & $1 \cdot 9$ & $1 \cdot 6$ & - & $4 \cdot 0$ \\
\hline $4 \cdot 5$ & $4 \cdot 5$ & $\begin{array}{l}I \cdot 5 \\
I \cdot I\end{array}$ & $\begin{array}{l}3.9 \\
3 \cdot 3\end{array}$ & $\begin{array}{l}1 \cdot 30 \\
1 \cdot 58\end{array}$ & $\begin{array}{l}4 \cdot 5 \\
5 \cdot 3\end{array}$ \\
\hline $4 \cdot 7$ & & $I \cdot 4$ & $4 \cdot 0$ & $I \cdot 43$ & $4 \cdot 7$ \\
\hline $5 \cdot 0$ & $5 \cdot 0$ & $\begin{array}{l}\mathbf{I} \cdot 2 \\
0.8\end{array}$ & $\begin{array}{l}3 \cdot 9 \\
2 \cdot 3\end{array}$ & $\begin{array}{l}1 \cdot 63 \\
1 \cdot 45\end{array}$ & $\begin{array}{l}5 \cdot 3 \\
5 \cdot 5\end{array}$ \\
\hline & $5 \cdot 5$ & $1 \cdot 0$ & $2 \cdot 7$ & $1 \cdot 30$ & $5 \cdot 7$ \\
\hline & $6 \cdot 0$ & 0.9 & $I \cdot 9$ & $\mathrm{I} \cdot \mathrm{O} 4$ & $5 \cdot 9$ \\
\hline & $6 \cdot 5$ & 0.8 & $I \cdot 6$ & 1.00 & $6 \cdot 2$ \\
\hline
\end{tabular}

avidin (0.05 units $\mathrm{ml}^{-1}$; Sigma) which should have removed any residual biotin from the medium. Growth ceased in the second subculture (Fig. 2). The inhibitory effect of avidin was prevented in cultures having $0.4 \mu \mathrm{g}$ biotin $\mathrm{ml}^{-1}$. (I unit of avidin is defined by the supplier as the amount which binds $\mathrm{I} \mu \mathrm{g}$ of biotin.)

\section{Iron inhibition}

Specific inhibition of amoebal growth by ferrous ions was originally indicated by tests carried out on $P$. polycephalum amoebae fed on formalin-killed $E$. coli on agar supplemented with solutions of various inorganic salts (Holt \& Dee, unpublished results). Thus we suspected iron inhibition in the present work when growth ceased in the fourth subculture in AV-40, which has a much higher ferrous ion content than SD and BTC. When amoebae were grown in SD medium supplemented with ferrous ions at the level used in AV-40, reduced yields were obtained in three successive subcultures (Table 2).

\section{Optiwum $\mathrm{pH}$}

The optimum $\mathrm{pH}$ for growth was determined in SD medium by adjusting the citratephosphate buffer to give $\mathrm{pH}$ values in the range 3.5 to $6 \cdot 0$. Best growth was obtained between pH $4 \cdot 5$ and $5 \cdot 0$ (Table 3 ). 


\section{Large-volume cultures in enriched media}

Large-scale cultures of RSD4 have been successfully grown in modified Goodman medium, yielding sufficient quantities of amoebae for comparative studies of plasmodial and amoebal ribosomal RNA (Hall, Turnock \& Cox, 1975). Large-volume cultures (500 $\mathrm{ml}$ ) have now also been grown in SD medium in 21 conical flasks which had indentations to increase aeration. After adding $50 \mathrm{ml}$ extra water to allow for evaporation, the medium was autoclaved in the flask which was plugged with a foam bung and covered with aluminium foil. Each flask was inoculated with a $50 \mathrm{ml}$ culture of RSD4 amoebae in SD medium (approximately $10^{7}$ cells $/ \mathrm{ml}$ ) and incubated on a rotary shaker $(70 \mathrm{rev} . / \mathrm{min})$. Total yield after 6 days was $5.4 \times 10^{9}$ cells. Calculations based on published data indicate that this number of cells should yield 3.25 mg DNA (Mohberg \& Rusch, 197I) and $215 \mathrm{mg}$ protein (J. Mohberg, personal communication). In the large-volume SD cultures, the amoebae tended to form clumps but this was not observed in modified Goodman medium. Recent experiments have indicated that clumping may be eliminated by altering the composition of the buffered salts solution.

\section{DISCUSSION}

Although the minimal requirements of $P$. polycephalum amoebae have not yet been defined, it is clear that they will not differ greatly from those of the plasmodia. So far, the only absolute requirements identified in amoebae are for the same three vitamins and the one amino acid (methionine) which are specifically required by plasmodia. This result was unexpected in view of the repeated failures in our own and other laboratories to culture the amoebae on any of the defined or semi-defined media developed for $P$. polycephalum plasmodia. These failures, together with the obvious morphological and functional differences between the two stages and differences in gene expression revealed by genetic studies (Dee, 1975), led us to suppose that the nutritional requirements of amoebae might be different from and more complex than those of plasmodia. The only evidence so far of a requirement in amoebae which is not present in plasmodia is the stimulation of growth by leucine. However, it is not yet clear if this indicates an absolute requirement for leucine nor whether this requirement demonstrated in RSD4 will be shown by other strains. Work is in progress to define the specific requirements of several strains of amoebae including RSD4 and CLd.

Henney \& Asgari (1975) have recently cultured both amoebae and plasmodia of $P$. flavicomum in a defined minimal medium containing only three vitamins and three amino acids. They attributed their success in culturing amoebae on defined media, after many previous failures, to the gradual adaptation of the cells to nutritionally simpler media and the use of large inocula (about $10^{6}$ cells $/ \mathrm{ml}$ ) in the initial cultures. There was evidence that $P$. polycephalum RSD4 amoebae underwent a process of adaptation when first cultured in SD medium since there was an initial period of several weeks during which growth was very poor. Similar lag periods were observed in several other strains when first cultured in axenic media. The use of large inocula was also important in $P$. polycephalum, since initial cell numbers smaller than $5 \times 10^{5}$ cells $/ \mathrm{ml}$ frequently failed to give viable cultures.

Physarum polycephalum amoebae cultured on a lawn of E. coli, on the surface of agar or moist filter paper at $25^{\circ} \mathrm{C}$, feed by phagocytosis and multiply with a doubling time of 6 to 8 hours - a growth rate similar to the fastest observed in plasmodia on rich axenic media. Amoebal doubling times in liquid axenic media are considerably longer. Preliminary attempts to culture amoebae on semi-defined agar media without bacteria have not been 
successful. For the isolation of nutritional mutants in amoebae, growth on agar-based fully defined media will be essential. However, with the liquid defined media already available, it is possible to test for nutritional requirements in amoebae carrying mutations identified in auxotrophic plasmodia (Cooke \& Dee, 1975).

This work was supported by a Science Research Council grant (no. B/RG/49I03) which we acknowledge with thanks. We also wish to thank Professor C. E. Holt and Mr L. Davidow for permission to quote unpublished results and our colleagues, in particular Dr Joyce Mohberg, for helpful discussion.

\section{REFERENCES}

COOKe, D. J. \& DeE, J. (1974). Plasmodium formation without change in nuclear DNA content in Physarum polycephalum. Genetical Research 23, 307-317.

COOKe, D. J. \& DeE, J. (1975). Methods for the isolation and analysis of plasmodial mutants in Physarum polycephalum. Genetical Research 24, $175-187$.

Daniel, J. W. \& Baldwin, H. H. (I994). Methods of culture for plasmodial myxomycetes. In Methods in Cell Physiology, vol. I, pp. 9-4I. Edited by D. M. Prescott. New York: Academic.

Daniel, J. W., Babcock, K. L., Sievert, A. H. \& RuSCH, H. P. (I963). Organic requirements and synthetic media for growth of the myxomycete Physarum polycephalum. Journal of Bacteriology 86, 324-33I.

DeE, J. (1975). Slime moulds in biological research. Science Progress, Oxford 62, 523-542.

Goodman, E. M. (1972). Axenic culture of myxamoebae of the myxomycete Physarum polycephalum. Journal of Bacteriology III, 242-247.

Hall, L., Turnock, G. \& Cox, B. J. (I975). Ribosomal RNA genes in the amoebal and plasmodial forms of the slime mould Physarum polycephalum. European Journal of Biochemistry 5I, 459-465.

Haugli, F. B. (197I). Mutagenesis, selection and genetic analysis in Physarum polycephalum. Ph.D. thesis, University of Wisconsin, U.S.A.

Henney, H. R. \& AsGari, M. (I975). Growth of the haploid phase of the myxomycete Physarum flavicomum in defined minimal medium. Archives of Microbiology 102, 175-178.

Henney, H. R. \& Henney, M. R. (I968). Nutritional requirements for the growth in pure culture of the myxomycete Physarum rigidum and related species. Journal of General Microbiology 53, 333-339.

Henney, H. R., AsGari, M. \& Henney, M. R. (1974). Growth of the haploid and diploid phases of Physarum flavicomum in the same partially defined media. Canadian Journal of Microbiology 20, 967-970.

Hüttermann, A. (1973). Physarum polycephalum: object of research in cell biology. Berichte der Deutschen botanischen Gesellschaft 86, I-I 79.

MohberG, J. \& RUSCH, H. P. (197I). Isolation and DNA content of nuclei of Physarum polycephalum. Experimental Cell Research 66, 305-316.

Wheals, A. E. (I973). Developmental mutants in a homothallic strain of Physarum polycephalum. Genetical Research 21, 79-86. 